\title{
Land-use/vegetation cover and soil erosion impacts on soil properties of hilly slopes in Drama Prefecture of Northern Greece
}

\author{
George N. ZAIMES, K. KAYIAOGLU, A. KOZANIDIS
}

Eastern Macedonia and Thrace Institute of Technology, Dept. of Forestry and Natural Environment

Management, Drama, GREECE

*Corresponding author: zaimesgeorge@gmail.com

Received Date: 23.03.2017

Accepted Date: 09.06.2017

\begin{abstract}
Aim of study: Soil erosion is one of the most serious threats because of the multiple effects it has on society. The Mediterranean region is extremely susceptible to severe erosion because of the inappropriate agricultural management, overgrazing, deforestation, wildfires, land abandonment, urbanization, etc. Land-use/vegetation cover has a major impact on soil erosion and soil properties. The aim of this study was to compare soil properties of slopes of hills with three different land-uses/vegetation covers.

Area of study: The study was conducted on different slopes along Menoikio Mountain of the Prefecture of Drama in Greece.

Material and Methods: The three different land-uses/vegetation covers investigated were: a) cultivated areas, b) grazed rangelands and c) forested areas. Each slope had all three land-uses/vegetation covers and was separated in three parts: a) top, b) middle and c) bottom slope. Five soil samples were collected from each part. The soil samples were analyzed in the laboratory for the following soil properties: a) clay, silt and sand percentage, b) soil texture, c) soil density, d) soil moisture, e) $\mathrm{pH}$ and f) organic matter.

Main results: Significant differences among the three land-uses/vegetation covers were expected to be found because of the difference in soil erosion rates and also among the three slope parts because of the difference in erosional and depositional process that take place. This was not the case because in some soil variables other parameters e.g. other management practices in the three land-uses (grazing in the forested areas) were as influential.

Highlights: Examines land-use/vegetation cover implications on soil properties due to erosional and depositional process along a slope and provides insights to land managers of Greece in regards to soil management practices in order to promote sustainability.
\end{abstract}

Keywords: Agricultural practices, Forested areas, Slope position, Climate change

\section{Kuzey Yunanistan'ın Drama bölgesinde kara kullanımının/bitki örtüsünün ve toprak erozyonunun engebeli yamaçlardaki toprak \\ özelliklerine olan etkisi}

\section{Özet}

Çalı̧̧manın amacı: Toplum üzerine olan birçok etkisinden dolayı, toprak erozyonu en ciddi tehlikelerden biridir. Akdeniz Bölgesi; uygun olmayan tarımsal yönetim, aşırı otlatma, ormansızlaşma, orman yangınları, terk edilmiş araziler, şehirleșme vb. nedenler sebebiyle erozyona oldukça duyarlıdır. Arazi kullanımı/bitki örtüsü toprak erozyonu ve toprak özellikleri üzerinde büyük bir etkiye sahiptir. Bu çalışmanın amacı, üç farklı arazi kullanımı/bitki örtüsünde tepe yamaçlarının toprak özelliklerini karşılaştırmaktır.

Çalışma Alanı: Çalışma, Yunanistan'da Drama Bölgesi Menoikio Dağı boyunca farklı yamaçlar üzerinde yürütülmüştür.

Materyal ve Yöntem: Araştırılan üç farklı arazi kullanımını/bitki örtüsünü a) ekili alanlar b) otlatılan meralar ve c) ormanlık alanlar oluşturmaktadır. Her yamaç üç farklı arazi kullanımını/bitki örtüsünü barındırıp, a) üst, b) orta ve c) alt yamaç olmak üzere üç kısma ayrılmıștır. Her kısımdan beș adet toprak örneği toplanmıștır. Toplanan toprak örnekleri: a) kil, silt ve kum yüzdesi, b) toprak tekstürü, c) toprak yoğunluğu, d) toprak nemi, e) pH ve f) organik madde gibi toprak özelliklerini belirlemek için laboratuvarda analiz edilmiştir.

Sonuçlar: Toprak erozyon oranlarındaki farklılık nedeniyle üç arazi kullanımı/bitki örtüsü arasında önemli farklılıkların bulunması ve aynı şekilde, gerçekleşen erozyon ve çökelme sürecindeki farklılık nedeniyle üç yamaç kısmı arasında da önemli farklılıkların gözlemlenmesi beklenmekteydi. Bazı toprak özelliklerindeki diğer değişkenler örneğin, üç farklı arazi kullanımındaki diğer yönetim uygulamaları (ormanlık alanda otlatma) sebebiyle sonuçlar beklenilen şekilde değildi.

Araştırma Vurguları: Bu çalışma, bir yamaç boyunca erozyon ve birikme süreçleri nedeniyle arazi kullanımının/bitki örtüsünün toprak özellikleri üzerine olan etkilerini inceler ve sürdürülebilirliği teşvik etmek için toprak yönetim uygulamaları hakkında Yunanistan'ın arazi yöneticilerine fikir verir.

Anahtar kelimeler: :Tarımsal uygulamalar, ormanlık alanlar, yamaç konumu, iklim değişikliği 


\section{Introduction}

Soil erosion is considered a major threat because it has many negative implications on humans, society and the environment (Yang et al., 2003). While soil erosion is a natural phenomenon, agriculture, deforestation, urbanization and other anthropogenic activities have accelerated its rates (Montgomery, 2007). This has led to soil erosion prevention being a major task for most countries with the development and implementation of numerous soil conservation efforts to achieve soil sustainability.

Soil erosion leads to the loss of the top soil; the most fertile and productive soil (Lal and Stewart, 1990; Pimentel et al., 1995). This has major impacts on agricultural production (substantial decrease) and food cost (substantial increase due to use of more fertilizers). Erosion decreases soil quality (by decreasing soil depth, water availability and soil organic matter along with increasing nutrient loss) and in natural ecosystems can lead to their degradation and consequently to the desertification of these regions (Pimentel, 2006). This should be no surprise since it has been reported that approximately 75 billion tons of soil are eroded yearly (Pimentel and Kounang, 1998). In agricultural areas the soil erosion rates can range from 13 tons/ha/year to 40 tons/ha/year (Pimentel and Kounang, 1998). Soil loss in agricultural areas is 13-40 times faster than the soil renewal rate (soil forms slowly) (Pimentel and Kounang, 1998). This clearly indicates that soil sustainability will be very difficult to be achieved without a good understanding of the implication of soil erosion.

Climate changes will also impact soil erosion. The new thermal conditions, rainfall amounts and intensities, number of days of precipitation, ratio of rain to snow, will impact plant biomass production, plant residue decomposition rates, soil microbial activity, evapotranspiration rates and potentially cause shifts in land-uses (Nearing et al., 2004). The many changes make it difficult to predict the exact impacts but the expected increase in extreme weather events, particularly the increased rainfall intensity and extended drought periods compared to past conditions (Giupponi and Shechter,
2003), should lead to higher surface runoff, higher sediment transport capacity and increased surface soil erosion.

In Europe, the Mediterranean region seems to be the most susceptible to soil erosion, land degradation and desertification (Cerdan et al., 2011; García-Ruiz 2010). This is due to the natural characteristics of the region, specifically the semi-arid climate, sparse vegetation and steep topography (Davidson, 1991; Zaimes et al., 2012). Another major factor is the frequent wildfires in the region that are a natural part of the ecosystem (Shakesby, 2011). Burnt areas have very high erosion rates, and if appropriate conservation measures are not taken in a short period of time after the wildfire excessive erosion and flooding should be expected (Nearing et al., 2008; Ranis et al., 2015). Finally, the region has been inhabited by humans for thousands of years that have heavily impacted it (Pearce, 1996; Tal, 2006). Human inhabitation impacts are very evident in the many unsustainable agricultural lands of the region and the few remaining patches of natural ecosystems.

This study focuses on soil erosion in Greece. Minimal systematic and holistic efforts have been done to reduce erosion despite $26.5 \%$ of the country's total land area experiencing severe soil erosion problems (Mitsios et al., 1995). Soil erosion is beginning to be recognized as a problem in Greece since the number of publications and research projects conducted have increased in the last decades (Koutalakis et al., 2015). Still less emphasis has been given to the changes in soil properties due to surficial soil erosion. A key factor that influences soil erosion is land-use/vegetation cover. Specifically areas with perennial vegetation (e.g. forests) have substantially less surface erosion than cultivated areas. The perennial cover reduces the impacts of the rainfall drops; increases infiltration rates and protects the soil for surface runoff thus are less susceptible to erosion (Kosmas et al., 1997; Zaimes et al., 2012). Overgrazing can lead to bare areas by trampling and increase compaction that enhances surface runoff and surface erosion compared to undistributed 
areas (Yates et al., 2000) thus increasing soil erosion vulnerability.

The objective of this study was to investigate the impacts of surficial erosion on soil properties. Soil properties were investigated along slopes under different land-uses/vegetation covers. Different landuses/vegetation covers should have different soil erosion rates that should impact soil properties. In addition, the spatial impacts (slope location) of soil erosion and deposition on soil properties were investigated. Specifically we investigated if the different parts of a slope (top, middle, bottom) that experience either different erosion rates or deposition had different soil properties.

\section{Material and Methods Study Areas}
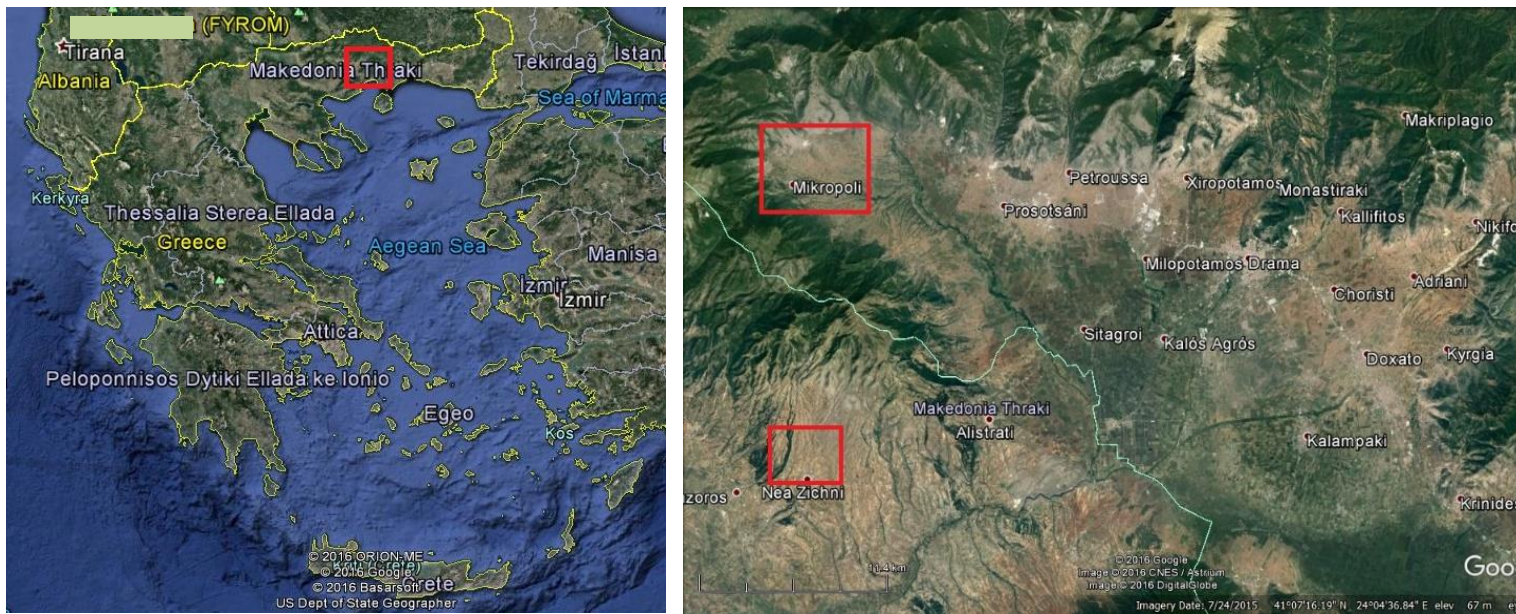

Figure 1. The location of Menoikio Mountain in Greece (red rectangle, map on the left). The two study areas were near the towns Micropoli (area 1) and Nea Zichni (area 2) (red rectangles, map on the right) of Drama Prefect. In each area, three plots were selected and soil samples were collected (source: Google Earth).

The two study areas were near the towns of Micropoli and Nea Zichni (Figure 1). In each area three slopes with different landuses/vegetation covers representative of the region were selected. Specifically these were: a) forested areas, b) grazed rangelands and c) cultivated areas. These plots were relatively close to each other to have similar climatic conditions and soils that should not influence the erosional process and soil properties. Finally, the slopes of all plots ranged from $15-25 \%$.
The study areas were along foothills of Menoikio Mountain (Figure 1) located in the Eastern Macedonia Region of North Greece (Longitude: E $23^{\circ} 48^{\prime} 0$ ", Latitude: $41^{\circ} 10^{\prime}$ 00 "). All the study areas were located in Drama Prefecture. The climate of the region is Mediterranean with precipitation that ranges from $600-1000 \mathrm{~mm} \mathrm{yr}^{-1}$ (Ministry of Development, National Technical University of Athens, Institute of Geological and Mining Research, and Centre for Research and Planning, 2003). The existing fauna and flora of the Menoikio Mountain is unique with many rare plant and wildlife species. For this reason, it has been designated as a protected area in the "Natura 2000" Network, a European Union's policy to protect and enhance the biodiversity of special importance areas. 
depositional processes. In each slope part, 5 different soil samples (5 replications) were taken. The 5 replications were approximately $50 \mathrm{~m}$ apart along a transect perpendicular to the slope. The soil samples were taken with a soil auger and had a depth of $5 \mathrm{~cm}$. The total number of soil samples taken from all landuses was 90. The soil samples were afterwards transferred to the laboratory for analysis. In the laboratory the samples were analyzed for the following soil parameters: a) clay, silt and sand percentage, b) soil texture, c) soil density, d) soil moisture, e) $\mathrm{pH}$ and f) organic matter. For the analysis, the standard methods were used (Clute, 1986). The analysis was conducted at the Laboratory of Forest Edaphology of the Department of Forestry and Natural Environment Management, Eastern Macedonia and Thrace Institute of Technology.

\section{Results and Discussion}

In all soils samples collected the dominant mineral was sand (Table 1). Specifically sand was always greater than $75 \%$ and in most cases greater than $80 \%$. The high percentage of sand is a clear indication of erosion. The fines particles of clay and silt have been eroded by surface runoff.

The soil texture in the cultivated area of all parts of the slope in area 2 were Loamy Sands while in area 1 we did find a spatial difference since the top and middle parts were Sandy Loams and the bottom Loamy Sand. In the rangelands again most parts of the slope were Loamy Sands. The only exception was the top part of area 1 that was Sandy indicating extensive erosion with a very small percentage of clay (less than $3 \%$ ).

Table 1. The average values of the soil properties for the two areas for the three different landuses/ vegetation covers. The soil properties studied were: a) sand, silt and clay percentage, b) texture, c) density, d) soil moisture e) $\mathrm{pH}$ and f) organic matter. Samples were collected along three parts of the slope (top, middle and bottom).

\begin{tabular}{|c|c|c|c|c|c|c|c|}
\hline \multirow{3}{*}{ Soil property } & \multirow{3}{*}{ Slope Part } & \multicolumn{6}{|c|}{ Land use/Vegetation cover } \\
\hline & & \multicolumn{2}{|c|}{ Cultivated Areas } & \multicolumn{2}{|c|}{ Grazed Rangeland } & \multicolumn{2}{|c|}{ Forested Areas } \\
\hline & & Area 1 & Area 2 & Area 1 & Area 2 & Area 1 & Area 2 \\
\hline \multirow[t]{3}{*}{ Sand $(\%)$} & Top & 77,57 & 82,70 & 86,74 & 87,94 & 83,26 & 84,10 \\
\hline & Middle & 76,61 & 78,81 & 86,06 & 87,18 & 85,04 & 80,30 \\
\hline & Bottom & 77,41 & 86,31 & 86,76 & 86,31 & 86,14 & 83,74 \\
\hline \multirow[t]{3}{*}{ Silt (\%) } & Top & 6,46 & 14,49 & 8,78 & 9,19 & 11,32 & 14,85 \\
\hline & Middle & 6,24 & 19,05 & 9,21 & 8,39 & 10,29 & 18,04 \\
\hline & Bottom & 20,31 & 11,40 & 8,28 & 9,15 & 10,86 & 13,79 \\
\hline \multirow[t]{3}{*}{ Clay (\%) } & Top & 15,97 & 2,82 & 4,48 & 2,87 & 5,42 & 1,06 \\
\hline & Middle & 17,15 & 2,14 & 4,74 & 4,43 & 4,66 & 1,66 \\
\hline & Bottom & 2,28 & 2,29 & 4,95 & 4,54 & 2,99 & 2,47 \\
\hline \multirow[t]{3}{*}{ Texture } & Top & SL & LS & LS & $\mathrm{S}$ & LS & LS \\
\hline & Middle & SL & LS & LS & LS & LS & LS \\
\hline & Bottom & LS & LS & LS & LS & LS & LS \\
\hline \multirow[t]{3}{*}{ Density $\left(\mathrm{gr} / \mathrm{cm}^{3}\right)$} & Top & 0.85 & 0.45 & 0.69 & 0.86 & 0.79 & 0.69 \\
\hline & Middle & 0.87 & 0.52 & 1.02 & 0.89 & 0.97 & 0.33 \\
\hline & Bottom & 1.05 & 0.70 & 0.96 & 0.97 & 0.93 & 0.46 \\
\hline \multirow[t]{3}{*}{ Soil Moisture (\%) } & Top & 22.34 & 19.88 & 47.98 & 37.38 & 37.38 & 25.14 \\
\hline & Middle & 17.35 & 21.35 & 38.05 & 32.19 & 32.19 & 23.86 \\
\hline & Bottom & 10.31 & 28.66 & 37.40 & 39.52 & 39.52 & 49.15 \\
\hline \multirow[t]{3}{*}{$\mathrm{pH}$} & Top & 7.6 & 7.4 & 7.6 & 7.5 & 7.4 & 7.8 \\
\hline & Middle & 7.5 & 7.6 & 7.5 & 7.5 & 7.4 & 7.7 \\
\hline & Bottom & 7.4 & 7.5 & 7.5 & 7.4 & 7.3 & 7.6 \\
\hline \multirow[t]{3}{*}{ Organic Matter (\%) } & Top & 6,50 & 4,11 & 2,59 & 2,55 & 3,92 & 4,29 \\
\hline & Middle & 4,96 & 3,66 & 3,71 & 2,46 & 2,68 & 4,91 \\
\hline & Bottom & 4,89 & 3,44 & 2,81 & 3,80 & 3,18 & 4,60 \\
\hline
\end{tabular}


Finally in all parts of the forested areas all soil textures were Loamy Sands. Kosmas et al. (2000) and Marzaioli et al. (2010) found no textural difference among land-use because these are more dependent on parent material.

Soil densities showed great variation based on land-uses/vegetation covers, areas and slope parts (Table 1). Overall the soils were not very heavily compacted. A study in Turkey found substantially higher bulk densities in cultivated $\left(1.33 \mathrm{gr} / \mathrm{cm}^{3}\right)$, pasture $\left(1.19 \mathrm{gr} / \mathrm{cm}^{3}\right)$, and forest $\left(1.25 \mathrm{gr} / \mathrm{cm}^{3}\right)$ areas compared to ours (Celik, 2005). In addition the differences among the land-uses in the study in Turkey were statistically significant (Celik, 2005). The grazed rangelands in this study had the highest soil densities ranging from $0.69-1.02 \mathrm{gr} / \mathrm{cm}^{3}$. The cultivated and forested areas had wider ranges with 0.45 1.05 and $0.33-0.97 \mathrm{gr} / \mathrm{cm}^{3}$, respectively. It was also very evident that the cultivated and forested areas were substantially more compacted in area 1 than in area 2 . This is probably due to different management practices in the cultivated fields and the grazing impacts on the forested areas (in Greece many forested areas are grazed). For the rangelands the compactions in both areas were similar indicating the impact of livestock trampling. Finally soil densities, appeared to be higher in the bottom part of the cultivated areas, while there was no true pattern for the other two land-uses/vegetation covers.

As expected the cultivated areas, with the low typically infiltration rates, had the least soil moisture ranging from just $10.31 \%$ up to $28.66 \%$ (Table 1). Dunjo et al. (2002) found forested areas had great water holding capacity than cultivated fields. The soil moisture of the other two landuses/vegetation covers was similar although it appears that grazed rangelands had higher values (Table 1). This is probably related to the interception in the forested areas by the tree canopies. Finally, only the forested areas showed a consistent spatial pattern with the bottom parts having the most soil moisture and the middle parts the least. Most moisture was expected to be in the bottom parts that should accumulated the water moving from the upslope areas.
Moving on to the $\mathrm{pH}$ the values ranged from 7.4-7.8 (Table 1). The cultivated and rangeland areas had the smallest range of values (7.4-7.6). The cultivated areas had no apparent spatial pattern, while the rangeland $\mathrm{pH}$ values appeared slightly decreased as you move downslope. Finally in the forested areas, the $\mathrm{pH}$ again seems to be slightly decreased moving downslope. The two areas had differences in the $\mathrm{pH}$ values, with area 1 (7.4-7.5) lower than area 2 (7.6-7.8). In almost all parts of all land-uses/vegetation covers the soil $\mathrm{pH}$ were considered neutral (6.5-7.5) except in the forested area 2 that was considered alkaline (> 7.5). Other studies have also found no significant $\mathrm{pH}$ differences among land-uses (Kosmas et al., 2000) because they are more related to the parent material than the land-uses (Dunjo et al., 2002).

The most surprising results were in regards to the percentage of organic matter. Other studies have shown that forested and natural grass areas and pastures had higher percentages of organic matter than cultivated areas (Caravaca et al., 2002; Celik, 2005; Dunjo et al., 2002). Still one study did not find significant different among between cultivated and abandoned areas (Kosmas et al., 2000). In this study the cultivated areas had the highest percentage of organic matter. This is probably related to the management practices of cultivated areas that probably involve no till. In addition, the organic matter seems to be decreasing as we move downslope. Most parts of the cultivated fields were rich $(3-5 \%)$ in organic matter while one was very rich $(>5 \%)$. For the rangelands most slope parts had medium organic matter (2-3\%) while two parts were considered rich. Finally, in the forested areas all parts were considered rich in organic matter except one that was medium. Overall all three land-uses/vegetation covers had sufficient organic matter in their soils.

\section{Conclusions}

More distinct differences among landuses/vegetation covers and along the slope parts were expected. The few expected differences found probably have to do with two facts. Firstly even in the forested areas grazing probably takes place that has impacts 
on soil properties. The other probably has to with the number of soil samples and replications of land-uses/vegetation covers. Having a larger soil sample size with more replications would probably provide better differences. Still this is a very important first study that looks into land-use/vegetation cover implications on soil properties due to erosional and depositional process along a slope and can provide insights to land managers of Greece in regards to soil management practices to achieve sustainability.

\section{References}

Caravaca, F., Masciandaro, G., Ceccanti, B. (2002, October). Land use in relation to soil chemical and biochemical properties in a semiarid Mediterranean environment. Soil \& Tillage Research, 68, 23-30. doi.org/10.1016/S0167-1987(02)00080-6

Celik, I. (2005, September). Land-use effects on organic matter and physical properties of soil in a southern Mediterranean highland of Turkey. Soil \& Tillage Research, 83, 270-277. doi.org/10.1016/j.still.2004.08.001

Cerdan, O., Desprats, J-F., Fouché, J., Le Bissonnais, Y., Cheviron, B., Simonneaux, V., Raclot, D., Mouillot, F. (2011). Impact of global changes on soil vulnerability in the Mediterranean Basin. ASABE - International Symposium on Erosion and Landscape Evolution, (pp 495- 503).

Clute, A. (Ed.). (1986). Methods of soil analysis: Part 1. Physical and Mineralogical Methods. $2^{\text {nd }}$ ed. Madison, WI :American Society of Agronomy and Soil Science Society of America.

Davidson, A.D. (1991, January). Soil erosion in the Mediterranean Basin. Geography 76, 71-73

Dunjo, G., Pardini, G., Gispert, M. (2002, May). Land use change effects on abandoned terraced soils in a Mediterranean catchment, NE Spain. Catena 52, 23- 37. doi.org/10.1016/S0341-8162(02)00148-0

García-Ruiz, J.M. (2010, April). The effects of land uses on soil erosion in Spain: A review. Catena, 81, 1-11. doi.org/10.1016/j.catena.2010.01.001
Giupponi C., Shechter M. (eds.) (2003) Climate change in the Mediterranean: Socio-economic perspectives of impacts, vulnerability and adaptation. Glos, UK: Edward Elgar Publications.

Kosmas, C., Danalatos, N., Cammeraat, L.H., Chabart, M., Diamantopoulos, J., Farand, R., Gutierrez, L., Jacob, A., Marques, H., Martinez-Fernandez, J., Mizara, A., Moustakas, N., Nicolau, J.M., Oliveros, C., Pinna, G., Puddu, R., Puigdefabregas, J., Roxo, M., Simao, A., Stamou, G., Tomasi, N., Usai, D., Vacca, A.. (1997, March). The effect of land use on runoff and soil erosion rates under Mediterranean conditions. Catena, 29, 45$59 . \quad$ doi.org/10.1016/S03418162(96)00062-8

Kosmas, C., Gerontidis, St., Marathianou, M. (2000, June). The effect of land use change on soils and vegetation over various lithological formations on Lesvos Greece. Catena, 40, 51-6. doi.org/10.1016/S0341-8162(99)00064-8

Lal, R., Stewart, B.A. (1990). Soil degradation. New York, NY: SpringerVerlag.

Marzaioli, R., D'Ascoli, R., De Pascale, R.A., Rutigliano, F.A. (2010, March). Soil quality in a Mediterranean area of Southern Italy as related to different land use types. Applied Soil Ecology 44, 205212. doi.org/10.1016/j.apsoil.2009.12.007

Ministry of Development (MoD), National Technical University of Athens (NTUA), Institute of Geological and Mining Research (IGME), and Centre for Research and Planning (KEPE). (2003). Master plan for water resource management of the country, Completion of the classification of quantitative and qualitative parameters of water resources in water districts of Greece. Athens, Greece: Department of Water Resources, Hydraulic and Maritime Engineering National Technical University of Athens, Ministry of Development. (In Greek).

Mitsios, J., Pashalidis, C., Panagias, K. (1995). Soil erosion - Mitigation techniques to soil erosion. Athens, Greece: Zymel Editions.

Montgomery, D.R. (2007, August). Soil erosion and agriculture sustainability. 
Proceedings of the National Academy of Science USA 104, 13268-13272. doi: 10.1073/pnas.0611508104

Nearing, M.A., Pruski, F.F., O'Neal, M.R. (2004, January). Expected climate change impacts on soil erosion rates: A review. Journal of Soil and Water Conservation 59, 43-50.

Pearce, F. (1996, July). Deserts on our doorstep. New Science 151, 12-13

Pimentel, D. (2006, February). Soil erosion: A food and environmental threat. Environment, Development and Sustainability 8, 119-137. doi: 10.1007/s10668-005-1262-8

Pimentel, D., Harvey, C., Resosudarmo, P., Sinclair, K., Kurz, D., McNair, M., Crist, S., Shpritz, 1., Fitton, L., Saffouri, R., Blair, R. (1995, February) Environmental and economic costs of soil erosion and conservation benefits. Science 267, 1117 1123.

Pimentel D., Kounang N. (1998, September). Ecology of soil erosion in ecosystems. Ecosystems 1, 416-426 doi : $10.1007 / \mathrm{s} 100219900035$.

Ranis, G.D., Iakovoglou, V., Zaimes, G.N. (2015). Ecosystem Post-Wildfire Effects of Thasos Island. World Academy of Science, Engineering and Technology International Journal of Environmental,
Chemical, Ecological, Geological and Geophysical Engineering 9, 1242-1245. Retrieved from: http://waset.org/publications/10002836/ec osystem-post-wildfire-effects-of-thasosisland

Shakesby, R.A. (2011, April). Post-wildfire soil erosion in the Mediterranean: Review and future research directions. EarthScience Reviews 105, 71-100. doi.org/10.1016/j.earscirev.2011.01.001

Yates C.J., Norton D.A., Hobbs R.J. (2000, February). Grazing effects on plant cover, soil and microclimate in fragmented woodlands in south-western Australia: implications for restoration. Austral Ecology. 25, 36-47. doi: 10.1046/j.14429993.2000.01030.x

Tal, A. (2010). Desertification. In Uekötter F. (Ed.), The Turning Points of Environmental History. Pittsburgh, PA: University of Pittsburgh Press, (pp 146161).

Zaimes, G.N., Lee, K-H., Tufekcioglu, M., Long, L.A., Schultz, R.C., Isenhart, T.M. (2012). The effectiveness of riparian conservation practices in reducing sediment in iowa streams. In Hendricks B.P. (Ed.) Agricultural Research Updates. Vol. 2. Hauppauge, NY: Nova Science Publishers, Inc. (pp. 117-165). 